\title{
A Study on Production and Marketing of Poultry Products in Namakkal District, Tamil Nadu State
}

\section{OPEN ACCESS}

Manuscript ID:

ECO-2021-09034018

Volume: 9

Issue: 3

Month: June

Year: 2021

P-ISSN: 2319-961X

E-ISSN: 2582-0192

Received: 30.03.2021

Accepted: 05.05.2021

Published: 01.06.2021

Citation:

Gopalasundar, R. "A

Study on Production and

Marketing of Poultry

Products in Namakkal

District, Tamil Nadu State."

Shanlax International

Journal of Economics,

vol. 9 , no. 3,2021 ,

pp. 15-19.

DOI:

https://doi.org/10.34293/

economics.v9i3.4018

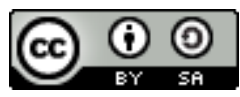

This work is licensed under a Creative Commons Attribution-ShareAlike 4.0 International License

\author{
R. Gopalasundar \\ Assistant Professor, PG and Research Department of Economics \\ Saraswathi Narayanan College (A), Madurai, Tamil Nadu, India \\ https://orcid.org/0000-0002-7291-4405
}

\begin{abstract}
The rural scenario in India is undergoing a rapid change, from the traditional concept of farming as a subsistence activity into a vibrant, commercial, economic venture enabling the farmers to live in dignity and prosperity. During the past four decades, the annual output of eggs has gone up by over eight times, and hence the marketing of poultry is the fast-growing industry. The development of farming has been given priority to help small rural farmers in the unorganized sector. It is also planned to ensure easy access to all necessary facilities, including inputs, credit and marketing. Hence, a study of the poultry industry and its commercial viability is of particular importance. Poultry farming is undertaken by thousands of rural as well as semi-urban masses. Poultry farming with low capital investment generates employment opportunities for rural and semi-urban people. With the new occupation and employment generation, the standard of living has considerably created a social impact.
\end{abstract}

Keywords: Business, Rural sector, Farms, Marketing, Economic, Products

\section{Introduction}

The rural scenario in India is undergoing a rapid change, from the traditional concept of farming as a subsistence activity into a vibrant, commercial, economic venture enabling the farmers to live in dignity and prosperity. During the past four decades, the annual output of eggs has gone up by over eight times, and hence the marketing of poultry is the fast-growing industry. The development of farming has been given priority to help small rural farmers in the unorganized sector. It is also planned to ensure easy access to all necessary facilities, including inputs, credit and marketing. Hence, a study of the poultry industry and its commercial viability is of particular importance.

Poultry farming is initiated by thousands of rural as well as semi-urban masses. Poultry farming with low capital investment produces employment opportunities for rural and semi-urban people. With the new occupation and employment generation, the standard of living has considerably created social impact.

During the early five-year plan periods, some progress has been made in upgrading the layer due to schemes sponsored by the central and state governments. The increase in the projects increased the size of farms and egg production. To expedite the poultry business, large influence farms were developed in Delhi, Simla, Bhuvaneswar, Bangalore, and Mumbai. The number and size of state poultry farms have increased, and some districts have more than 1000 farms. 


\section{Statement of the Problem}

Even though there is a vast scope for developing the poultry business, it has confronted the following problems.

The poultry industry is in poor shape including has become the victim of a vicious circle of high prices of feeding materials, low output prices, reduced earning, increased risk of mortality, low productivity and high cost of production.

Though the people concerned with the poultry business, such as the poultry farmers, the hatchery men, the feed manufacturers, the wholesalers, and the retailer, are all aware of its associated problems poultry, they are not in a position to evolve a controlled analysis. The researcher has made an earnest attempt to find the solution for the above problems.

\section{Objectives}

To overcome the above problems, the researcher took an in-depth study with the following objectives;

- To examine the current marketing practices undertaken by poultry farmers and other intermediaries in this trade.

- To study the problems faced by the manufacturer of poultry products.

- To find out the problems of marketing and offering a solution for it.

- To analyses whether the production increases the exports.

- To offer suggestions to overcome the problems of poultry farms.

\section{Hypotheses}

Bearing the above objectives in mind, the researcher has farmed the following hypothesis.

- $\mathrm{H}_{0}$ : Education plays a vital role in the successful management of poultry farms.

$\mathrm{H}_{1}$ : Education does not play a vital role in the successful management of poultry farms.

- $\mathrm{H}_{0}$ : There is no significant difference in the performance between old and new poultry farms. $\mathrm{H}_{1}$ : There is a significant difference in the performance between old and new poultry farms.

- $\mathrm{H}_{0}$ : There is no significant relationship between the production of eggs and the export level of eggs.
$\mathrm{H}_{1}$ : There is a significant relationship between the production of eggs and the export level of eggs.

\section{Selection of the Study Area}

Namakkal finds a place of influence in the map of India because it produces a significant part of Eggs and is sent all over other parts of our country, and is also called "Poultry Town" as it contains quite a several poultry Farms and now called "Egg City." There are Lorries, Trailers, and L.P.G. Tanker Lorries are in Namakkal district. More than 150 Lorry bodybuilding workshops and with several subsidiary industries of auto body works are operating since the 1960s. Therefore it is called a 'Transport City. "The famous Tamil Poet" Namakkal Kavingnar Ramalingam Pillai" was born in this district. In the memorize of the poet, the state government installed art and science college for women.

Rasipuram is another important taluk in Namakkal District. The Chief industry of the town is constructing. Pattunoolkarar, who belongs in Sourashtra Community, lives in large numbers in this town together with kaikolar. They are manufacturing Cotton Cloth and Silk Sarees. Another critical aspect of the taluk is the Sago production. Nearly 176 Sago factories are placed in and around the Rasipuram Taluk. Sago and Starch products are exported to other countries; Ghee production is also famous in Rasipuram Taluk.

\section{Methodology of the Study}

Both primary and secondary data have been used for this study. A personal interview, with the help of a structured schedule, was adopted to collect preliminary data. The program was pre-tested and modified in light of the experience gained by the researcher in his pilot study. There are about 800 poultry farms in the Namakkal district. The researcher has collected a sample of 160 units from the total population by adopting Stratified Random Sampling. Since the number of retailers and wholesalers is invariably high, the researcher has adopted convenience random sampling to collect data from them.

In addition to this, a personal inquiry was made with some small retailers to get first-hand information 
on the retail poultry business. An oral interview was also conducted with officials of banks, "Revenue department, Block development offices and District Industries Center" to improve this study.

Secondary data have also been collected from some standard textbooks on poultry fannings like Poultry Industry yearbook, poultry magazines National Egg Co-ordination Committee (NECC) and other journals and newspapers. The collected data are tabulated and analyzed with simple statistical tools.

\section{Database and Period of the Study}

The study has employed both primary data and secondary data. The respondents collected the data by using the interview schedule method from February 2019 to February 2020.

\section{Statistical Tools Used}

For this research, the following statistical tools were followed

- Chi-square test

- Garrett ranking techniques

- Correlation

\section{Findings}

The study conducted so is summarized as follows

- The average age of poultry farmers was found to be above 50 years.

- Most of the respondent's education qualification was middle school level.

- It could be inferred that poultry farming is main or primary occupation and a subsidiary or secondary source of work.

- The average number of years of business experience in poultry farming of the sample was found to be 10 to 15 years.

- A maximum number of the respondent believed it was easy to get a loan, and followed by that, the poultry farmers thought it was easy to start the business.

- The majority of the respondents expressed that they had chosen the poultry farm in and around Namakkal because it was to enjoy the benefits of the business.

- The numbers of broilers reared in a farm in and around Namakkal were found to be 1,000 to 5,000 birds per month.

- A maximum layer type of chicks reared in a month was found to be more than 50,000 layers.

- A majority number of respondents were adopting the cage system. The layer-type chicks farming were adopting a cage system, and the broiler type of chick farms was adopting a deep litter system.

- A majority of the respondents felt that there were problems in the availing of veterinary services.

- Most of the respondents procured chicks from local. While on further investigation, it was found that broiler chicks were procured mostly from Palladam, and grower chicks were procured from Namakkal.

- A majority of the respondents felt problems with the high cost of chick in the chick supply.

- A maximum of 31.4 percent of respondents less than 10000 eggs were produced by poultry farms in and around Namakkal. The number of eggs got per day is estimated at 2.75 crores.

- Most of the (50.6 percentage) of respondents' investment in land and building was found to be above Rs. 1000000

- A majority (46.9 percentage) of respondents investments on equipment \& machinery was aboveRs. $8,00,000$.

- A majority (33.7 percentage) of respondents' infrastructure expenditure of the sample unit was from Rs. $1,00,000$ to Rs.3,00.000. Most of the 50 percent of respondents' cost of the broiler chicks for the sample unit was less than Rs. 10,000 per month.

- A majority (55.7 percentage) of respondents cost of the chicks for the sample unit was more than.50,000 per month

- 35.3 percent of respondents' cost of layers for the sample unit was from Rs.50,000 to Rs $1,00,000$ per month.

- Most of the (48.8 percentage) of respondents' expenditure on starter feed for the sample unit was Rs.2,000 to 5,000 per day.

- A majority (41.2 percentage) of respondents' finisher food expenditure of the sample unit was Rs. 10,000 to Rs.30,000 for the poultry farm per day.

- An average of 27.5 percent of the respondent 
damage and rejects may be estimated at 11 percentage to 15 percentage.

- The majority of the eggs sold per day was Rs.1000-Rs.3000 to consumers and hotels, respectively.

- A maximum of the eggs sold per day was Rs.20,001 to Rs.50,000 for wholesalers and below Rs.20,000 for retailers.

- The majority of the chicks sold per day was Rs.500-Rs. 1000 to consumers and hotels.

- The Chicken sold per day was Rs.3001 to Rs.5000 for wholesalers and Rs.3001 to Rs. 5000 for retailers.

- On average, 45.6 percent of respondents sold manure for three months for Rs. 1000 to Rs.3000.

- Most of the delayed repayment problems were faced in credit sales by poultry keepers, as expressed by 90 out of 160 respondents.

- The sample respondents preferably adopted the sales boys for collection of dues from the customers.

- It was found that the majority of the poultry farm keepers of Namakkal were facing the problems of Fluctuation in price, uneconomic prices due to lack marketing facilities and lack market, information, and lack of transport and communication. Most of the affected poultry farmers faced the problem of Fluctuation in price and uneconomic prices.

- Age-wise classification of the sample respondents revealed that on average, 30 percent of the respondents belong to the age group of 20 to 30 , and 30 to 45 and above 45 years.

- Of the 40 respondents, most (60 of percentage respondents) are engaged in the poultry business for more than ten years.

- The researcher has identified that most (40 percentage) of respondents are having retailers as their customers.

- The study has made a clear revelation that 100 percent of the respondents sell goods on credit to meet stiff competition.

- The researcher found that a good number of (35 percent of the) information incurred above Rs.30,000 per month as expenses.

- Further, the analysis summarises that most of them (90 percentage) respondents receive financial assistance for carrying out their business.

- The study highlights that 38.9 percentage of sample respondents depend upon the banks for financial assistance.

- Another significant disclosure is that a majority (60 percentage) of the respondents have spent above Rs.30,000 for the purchase of eggs and birds per day.

- The researcher further found that 50 percent of the informants have purchased poultry products from the manufactures partly on cash and partly on a credit basis.

- The present study observed that a good number (40 percentage) of the respondents had expressed their wish that 1-1 Vi months was needed to repay dues.

- Another finding is that 100 percent of sample respondents have felt that fluctuations in the price of poultry products were the problem.

- Further analysis showed that the majority of the respondents were of the view that the excess demand and changing food habits of the customer is the main reason for the price fluctuation.

- On average, 38.9 percent of the sample farms have felt that fluctuations decrease the profit and lead to low sales.

- Yet another observation clearly shows that a majority (65 percentage) of the respondents have expressed that the competition level has been very high in the poultry business.

- The analysis on the effect of competition shows that at least 30 percent of the respondents face a decrease in competition.

- When the researcher attempted to study the steps taken to face the competition, 45 percent of sample respondents sell their products at a discount to meet the match.

- It has been found that 100 percent of the respondents encounter the problem of marketing their products.

- When their turnover was estimated that 55 percent of the respondents had reported a turnover of above Rs.30,000 per month.

- The overall analysis clearly shows that 100 percent of sample respondents think poultry business as a profitable business.

- When an attempt was made to the problem 
facing the wholesalers and retailers using Garret Ranking Techniques revels that the Changing food habit of the people is the foremost reason for the situation in marketing having a mean score of 67.9 .

- When the reasons for the increase in the Production of eggs were analyzed, it was found that an increase in the demand is the main reason for the rise in egg production.

- The exports of eggs have been shown a fluctuating trend due to the disease of chicks.

- The feed price has doubled in the last two years due to an increase in the raw materials used for manufacturing the feed.

- The increase in the price of eggs is due to the rise in the price of feed and other ingredients.

\section{Conclusion}

At present, the poultry industry is not only providing poultry products to millions of people with required nutritious food at reasonable prices but also providing gainful employment to a large proportion of illiterates and low-level literates in the society. The government should come forward to take various measures to develop the poultry industry. If poultry farming is undertaken at a more significant level than the present level by most farmers, the poultry industry will be more profitable, economical and efficient. By and large, the Namakkal have pioneered in poultry farming and become of this; it provides employment opportunity for many people. It earns a sizeable level of foreign exchange through poultry products and hence needs to encourage and extended the area of operation.

\section{References}

Abedullah, A. Maqbool, and K. Bukhsh. "Issues and Economics of Poultry Production: A Case Study of Faisalabad, Pakistan." Pakistan
Veterinary Journal, vol. 27, no. 1, 2007, pp. 25-28.

Adebayo, O.O., and R.G. Adeola. "Socio-Economics Factors Affecting Poultry Farmers in Ejigbo Local Government Area of Osun State." Journal of Human Ecology, vol. 18, no. 1, 2005, pp. 39-41.

Ahaotu, E.O., et al. "Marketing of Poultry and Poultry Products in Itu Local Government Area of Akwa Ibom State, Nigeria." International Journal of Environmental \& Agriculture Research, vol. 2, no. 8, 2016, pp. 93-95.

Chandrakumarmangalam, S., and S.C. Vetrivel. "A Study on Production and Marketing of Poultry Eggs in Tamilnadu - India (With Reference to Namakkal District)." International Journal of Poultry Science, vol. 11, no. 3, 2012, pp. 237-242.

Durgga Rani, V., and M.R. Subhadra. "Problems related to Farm Operations in Poultry Farming as Perceived by Farm Women." Veterinary World, vol. 2, no. 5, 2009, pp. 191-192.

Hofacre, Charles L. "The Health and Management of Poultry Production." International Society for Infectious Diseases, vol. 6, 2002.

Mathan Babu, R., and P.G. Thirumagal. "A Literature Review on Production and Marketing on the Products of Poultry in Tamilnadu." International Journal on Global Business Management \& Research, vol. 8, no. 2, 2019, pp. 44-52.

Sambidi, Pramod. Factors Affecting Plant Location Decisions of U. S. Broiler Executives. Acharya N. G. Ranga Agricultural University, 2003.

Ugwu, Daniel S. "Baseline Study of Small and Medium Scale Poultry Production in Enugu and Lagos States of Nigeria." World Journal of Agricultural Sciences, vol. 5, no. 1, 2009, pp. 27-33.

\section{Author Details}

Dr. R. Gopalasundar, Assistant Professor of Economics, PG and Research Department of Economics, Saraswathi Narayanan College (A), Madurai, Tamilnadu, India, Email ID: gopal.sundar612@gmail.com 